\title{
Regional Entrepreneurship Support Infrastructure: Volgograd Region Case Study
}

\author{
OLGA AKIMOVA \\ Economics and Entrepreneurship \\ Volgograd State Technical University \\ Lenin Avenue 28, Volgograd \\ RUSSIA \\ SERGEY VOLKOV, \\ Economics and Entrepreneurship \\ Volgograd State Technical University \\ Lenin Avenue 28, Volgograd \\ RUSSIA \\ VLADIMIR KABANOV \\ Economics and Entrepreneurship \\ Volgograd State Technical University \\ Lenin Avenue 28, Volgograd \\ RUSSIA \\ NATALIA KETKO \\ Informational systems in economics \\ Volgograd State Technical University \\ Lenin Avenue 28, Volgograd \\ RUSSIA \\ IRINA KUZLAEVA \\ Association (non-commercial partnership) \\ «Guarantee Fund of the Volgograd Region» \\ Zhukov Avenue 3, Volgograd \\ RUSSIA
}

Abstract: - In the paper, the complex analysis of the regional infrastructure of support of technological entrepreneurship of the Volgograd region, based on the statistical data reflecting the activity of enterprise structures is carried out. The scientific relevance of this research is related to the fact that technological entrepreneurship is a new type of enterprise that meets the requirements of the postindustrial period. The functioning of this type of entrepreneurship is based on a high-tech or knowledge-intensive idea, which contributes to the development of the environment. According to the results of the analysis, the main drawbacks of the regional infrastructure of support of technological entrepreneurship of the Volgograd region, which create barriers in the development of technological entrepreneurship. Based on the identified problems, measures have been developed to overcome them.

Key-Words: - Regional infrastructure, technological entrepreneurship, sustainable development, entrepreneurship infrastructure.

Received: October 21, 2019. Revised: May 19, 2020. Accepted: May 28, 2020.

Published: June 2, 2020. 


\section{Introduction}

It is generally recognized that the level of socio-economic development of the region depends on the level of the business system development and vice versa $[1 ; 2 ; 3 ; 4]$. The entrepreneurial activity contributes to the innovation development and forms a favorable business ecosystem of the territory. The western practice of spatial development shows that the regional authorities have been actively fighting for attracting business capital to their territory, creating the favorable financial, economic and institutional conditions for doing business. Thus, according to the conclusions of the economists, the economic efficiency of regional development, described by the neoclassical school, depends not only on the labor, capital or natural resources, but also on the level of entrepreneurial culture development.

In turn, the structural and functional changes in the system of the entrepreneurial culture development and the tandem existence of its elements under the influence of the modern scientific and technological progress lead to the process of the inevitable entrepreneurship structure transformation and the accompanying diversification of its types, both abroad and in Russia. The results of such technogenic transformations are catalyzing link in the chain of the technological entrepreneurship formation as a new challenge to the lack of stability in development of the modern economic space.

At the moment, the impressive diversity of the technological entrepreneurship spheres development generates a wide range of the different research areas for the examination of the semantic and functional interpretation features. So, the technological entrepreneurship nature and the specificities of its development in conditions of the innovative economy were discussed in the works of Khandramay A. A. [5], Dolinskya A. Yu. [6], Klechin Yu. I. [7], based on the research of the innovation ecosystem specifics in the development context of the domestic business environment. A detailed risk analysis of implementation of the commercial technology projects and the possible ways of addressing them proposed in the works of Khusaenov R. R. [8], Korzuk D. I. and Tekucheva S. N. [9], including investigating the differences in the technological entrepreneurship from other types of the entrepreneurial activity and presenting the functional-dynamic model of the technology company importance in the innovation process.

Based on the Russian scientist research, it is possible to distinguish the characteristic differences of the technological entrepreneurship from other types:

- the innovations that represent the functioning result of the technological business, don't have a direct connection with the social needs, but rather the opposite - the development of society and technology are the consequences of the application of innovations generated by implementation of the innovative projects;

- the innovation effectiveness is expressed not in reducing production costs, but in the emergence of new properties and characteristics of the product;

- the most significant incentive for the innovation synthesis is the creation of a new product that brings benefits, not profit.

Thus, the indicators of effective development of technological entrepreneurship are the indicators of scientific and technical innovations.

According to the data, presented in the report «The global innovation index $2018 »^{1}$ [10], which contains detailed information about the innovation activities of 126 countries and territories of the world, the undisputed leaders in the field of technological entrepreneurship are Switzerland (1st place), the Netherlands (2nd place) and Sweden (3rd place) to this day. In these countries, the scientific innovation got its most active development, as the advanced methods of creation and popularization of technological novelties accelerate the business development process - from the initial stage of development, start-up, to its monetization.

The Russian Federation, taking the 46th place in the world ranking, gives way even to the countries with unstable economic development scenario, including Greece and Ukraine. At the same time, the domestic business has all the necessary resources for its improvement: it shows sustainable growth, and also has a positive

\footnotetext{
${ }^{1}$ Suggested citation: Cornell University, INSEAD, and WIPO (2018)
} 
experience in implementing technological innovations. At the same time, the USA takes the 6th place in the rating, which is due to the high level of scientific and technological progress of America [11].

Based on the fact that in Russia the term "technological entrepreneurship" is extremely difficult to project on the sphere of the classical business because of its semantic uncertainty, there is one of the main problems of technological entrepreneurship development the complexity of a detailed assessment of its development level in the regions.

However, currently the attempts are made to overcome the above-mentioned problem, so Rosstat [12] develops the indicators characterizing technological entrepreneurship in Russia, which are located in the section "Science and innovation".

Based on the official data of the statistics service at the end of 2017, the innovative small and medium-sized enterprises accounted for about $7.5 \%$ in the sectoral structure of small and medium-sized businesses in Russia, while the share of small innovative enterprises is only $5.2 \%$ of the total number of small enterprises in the country.

A detailed analysis of the technological entrepreneurship development is presented in the form of the indicators characterizing the distribution of the innovative business in the Federal districts, which have the following values: the Central Federal district accounts for $8.6 \%$ of small and medium-sized innovative enterprises, the North-Western Federal district $7.6 \%$, the Southern Federal district $-7.5 \%$, the North Caucasus Federal district $-2.9 \%$, the Volga Federal district $-8.1 \%$, the Ural Federal district $-7.3 \%$, the Siberian Federal district $6.5 \%$, the Far Eastern Federal district - 5.5\%. In general, this distribution appears to be uniform, although not significant in terms of the percentage values. The least developed innovative entrepreneurship in the North Caucasus, which is primarily due to the traditional and moderate conservatism of the local business.

At the same time, the sectoral structure of the domestic innovative business is represented mainly by the research and development fields
$(28.5 \%)$, roofing $(14.3 \%)$, manufacturing (13.7\%), telecommunications $(11.4 \%)$ and industrial production $(9.6 \%)$.

Thus, having analyzed the data presented by Rosstat, it can be concluded that the technological entrepreneurship in Russia is not widespread, and, accordingly, it is a specific type of the business due to the weak susceptibility to innovation of the small business institute and the regions themselves, due to the innovation class lack to ensure post-industrial socio-economic development of the country and regions, due to the inefficiency of the state investment policy as the basis of industrial policy of the country and regions.

Creating a favorable business climate and conditions for doing business is one of the key tasks of the state program "Economic development and innovative economy", the details of which are set out in the sub-program "Development of small and medium-sized businesses", which defines the tools and mechanisms to achieve the goal.

The purpose of this examination is a comprehensive analysis of the regional infrastructure to support the technological entrepreneurship, identification of the state program problems and an attempt to develop recommendations for their solution. The object of the examination is the Volgograd region. The authors have formed the assumption that the negative trend in development of the regional small and medium-sized enterprises is caused by the extreme insufficiency and inaccessibility of the state support measures applied to it, as well as by the practical indifference of the technological entrepreneurship value for the qualitative transformation of the economy of the Volgograd region. As a part of the testing of this hypothesis, the method of a systematic approach was used, which contributes to a detailed analysis and constructive assessment of the overall structure of the research problems. The usage of the descriptive aspect of the chosen method implementation is due to the structural organization of the modern Russian economic environment, as well as its tendency to general transformation as a result of the new catalysts emergence for development of the individual elements. The information collection for the 
examination was carried out from open foreign and domestic statistical sources, as well as through interviews and face-to-face interviews.

\section{The technological entrepreneurship: regional dimension}

By the number of small and medium-sized enterprises in 2019, the Volgograd region ranks $20^{\text {th }}$ place among the regions of the Russian Federation. At the beginning of the year, 80.6 thousand small and medium-sized businesses were registered in the Volgograd region, including 54.1 thousand individual entrepreneurs, 24.1 thousand microenterprises, 2.3 thousand small enterprises and 180 medium-sized enterprises [12]. The available data show that there are not enough enterprises in the small business sector, which negatively affects the overall development of the region.

According to the results of the Federal statistical observation on the innovation activity of small and medium-sized businesses, held once every two years, to this date technological entrepreneurship in the Volgograd region is represented by the companies that implement their activities in the field of mining, manufacturing, electricity, gas and steam; air conditioning (except for trade in electricity, trade in the gaseous fuels supplied through the distribution networks, trade in steam and hot water (thermal energy)); water supply; sanitation, waste collection and disposal, pollution control activities. In other words, not all spheres of activity in the region are covered by high technologies, mainly mining companies, companies supplying various types of resources and companies engaged in various types of cleaning and utilization activities. All these companies have a high share of state funding, the presence of this feature allows us to conclude that they have the necessary financial resources to develop high-tech areas. Thus, one of the factors constraining the development of technological entrepreneurship in the region is the volume of financial resources at enterprises.

The share of its presence in the structure of small and medium-sized businesses in the region is $4.3 \%$. The total number of the enterprise employees engaged in the technological innovations increased by $19.7 \%$ compared to the index of the last evaluation period. Only $4.3 \%$ of the regional enterprises belong to the sphere of technological entrepreneurship, this indicator testifies to the low level of technological entrepreneurship spread in the business space of the Volgograd region. Despite the fact that it has increased as compared to previous periods, the share of companies belonging to the sphere of technological entrepreneurship is negligibly small. This also indicates that a very small number of companies use high-tech ideas and knowledge-intensive technologies in their business activities.

In the cost terms, the volume of shipped goods, works and services of the innovative orientation is equal to 217.9 million rubles, of which 94.7 million rubles were newly introduced or subjected to the significant technological changes over the past three years.

The costs share for the research and development of new products, services and methods of their production (transfer), as well as the implementation of new production processes in the total cost (capital and current) for the technological innovations is $29 \%$ or 274.7 million rubles [11]. As can be seen from official statistics, the share of the cost of research and development is only $29 \%$, while in developed countries, from $50 \%$ to $80 \%$ of the free financial resources of enterprises is allocated to research and development. The current situation is caused by an acute shortage of financial resources for small and medium-sized businesses, which necessitates the development of programs of state financial support for the development of technological entrepreneurship.

As examples of enterprises that have reached a certain technological level and planning activities to strengthen its position in the market by expanding production capacity, improving production efficiency or diversification of products, can result in LLC "Agropartner", LLC "Neman", Individual Entrepreneur Chernoivanov V. V., LLC "PF "Axios", LLC "Bolt-34", LLC "VP34", LLC NPP "Meteor-Kurs", LLC "NPO-Alfa", CJSC "Nalkom-SERVIS", LLC "Bioniks", 
LLC "Magistral", $\quad$ LLC "Mebelnov", LLC "Ruslan", LLC "Sun country", IE Head of $\mathrm{K}(\mathrm{F}) \mathrm{H}$ T. S. Salamatina, LLC "Univeco", LLC "Volgograd-Penoplast", LLC "Quers", LLC "Measuring systems", LLC "Aquatechplast", LLC "NPP Thermalkom", IE Solodovnik A. G., IE Ivanov V.V., LLC "Construction company "Yugsnab", - LLC "Voltechno", HCC "Golden fleece", LLC "STAR", LLC "Domovito", IE Head of $\mathrm{K}(\mathrm{F}) \mathrm{H}$ Pak Sergey Petrovich, LLC "DOP", LLC "ExpoPro", LLC "Matrix", IE Blinkov S. O., the agricultural supplying and marketing serving consumer cooperative "Pugachevsky", etc. [12]

In spite of the fact that in the specified list the individual enterprises and the organizations with different-scale fields of activity are presented, it should be noted that they are among the players forming shape of the technological entrepreneurship of the Volgograd region.

However, as can be seen from the results of the analysis of official statistical data reflecting the level of technological entrepreneurship development in the Volgograd Region and the breadth of various spheres of activity, these indicators are at a very low level. Thus, the sphere of technological entrepreneurship has been able to extend only to a narrow group of industries, mainly related to the extraction and supply of energy resources, and its penetration into the sphere that affects environmental protection and control of environmental standards is a positive development.

However, other areas continue to develop in an inefficient way, since they lack technological enterprises, namely, enterprises of technological entrepreneurship are the conductors of high-tech ideas and knowledge-intensive technologies into mass production and use.

The main barriers to the development of technological entrepreneurship in the region are: lack of financial resources and unfavorable development conditions (figure 2). By unfavourable conditions for development, the authors mean the lack of state support for technological entrepreneurship in all its possible forms and types.

Thus, the gradual increase in the number of innovative enterprises in the territory under consideration indicates that the regional aspect becomes more and more important in the implementation of innovative processes every year. That is why, in order to intensify the emergence of new and sustainable development of existing technology companies in the Volgograd region and, as a result, to bring the local technology business as a whole to a qualitatively new level, it is extremely important to pay special attention to the forms and methods of the state support, and mechanisms to stimulate innovation.

It should also be noted that the active introduction of various forms and methods of state support for technological entrepreneurship requires a detailed elaboration of measures included in this support. A detailed study, in turn, requires a thorough analysis of the environment for the development of technological entrepreneurship.

Since a certain support infrastructure already exists, it is necessary to analyze its functioning, identify the level of efficiency and the advantages and disadvantages and, based on the results, make a decision either to develop and implement a new, more efficient infrastructure or to upgrade an existing one, since upgrading an existing one is less expensive and at the same time faster than creating a new one.

According to the results of the analysis of the general state of technological entrepreneurship in the Volgograd region, there is an objective need to study the infrastructure to support it. Thus, the next stage of this research is the analysis of the infrastructure to support technological entrepreneurship.

\section{The infrastructure to support small and medium-sized businesses in the region}

The socio-economic benefits of enhancing development of the technological entrepreneurship for regional well-being in the recent years have generated a great deal of practical interest in the issue of mechanisms and forms of support for regional entrepreneurship systems.

According to the Federal law of July 24, 2007, №209-FZ "About development of small and medium-sized businesses in the Russian 
Federation", the infrastructure to support small and medium-sized businesses is a system of commercial and non-profit organizations that are created, operate or are involved as suppliers (performers, contractors) for the procurement of goods, works, services for the state and municipal needs in the implementation of Federal programs for development of small and mediumsized businesses, the regional programs for development of small and medium-sized businesses, the municipal programs for development of small and medium-sized businesses, providing conditions for the creation of small and medium-sized businesses, and to support them [11].

In general, development of the technological entrepreneurship in Russia is fixed by the various documents, some of which are worth highlighting:

- The concept of the long-term socioeconomic development of the Russian Federation for the period up to 2020;

- Strategy of innovative development of the Russian Federation for the period up to 2020;

- Forecast of scientific and technological development of the Russian Federation for the period up to 2030 .

In the Volgograd region, development of the entrepreneurship is supervised by the Committee for economic policy and development of the Volgograd region, within the structure of which the Department for development of the entrepreneurship was created, which duties include ensuring implementation of the state policy in the support field for development of small and medium-sized businesses.

According to the law of the Volgograd region of 25.12.2012, № 176-OD, the state innovation support in the Volgograd region is carried out in the following forms:

- provision of the tax benefits and reduced tax rates in accordance with the legislation of the Volgograd region;

- provision of the investment tax credit in accordance with the legislation of the Russian Federation and the legislation of the Volgograd region;

- provision of the state guarantees of the Volgograd region in accordance with the legislation of the Russian Federation and the legislation of the Volgograd region. This form of support implies that the state or region acts as a guarantor of payment of investments in risk situations, it allows attracting more investors, investments are insured at the state and regional levels;

- introduction of the subsidies from the regional budget in accordance with the legislation of the Russian Federation and the legislation of the Volgograd region;

- grants and awards in accordance with the legislation of the Russian Federation and the legislation of the Volgograd region;

- establishment of the reduction factor in determining the rent amount for the state property usage in the Volgograd region in accordance with the legislation of the Volgograd region;

- warranty of the rights to use intellectual property objects, the exclusive rights to which belong to the Volgograd region, in accordance with the legislation of the Russian Federation and the legislation of the Volgograd region;

- introduction of the state property of the Volgograd region, including means of the regional budget, as contributions to the authorized capitals of the joint-stock companies according to the legislation of the Russian Federation and the legislation of the Volgograd region.

Also, implementation of the state policy in support of the business system development in the Volgograd region is carried out through the regional target programs. The subprogram "Development and support of small and mediumsized businesses in the Volgograd region" has been operating since 2017, within the structure of the state program of the Volgograd region "Economic development and innovative economy". In addition, 38 municipal programs of the Volgograd region for development and support of small and medium-sized businesses have been developed and approved.

The assistance in implementation of the state policy for support and development of the small and medium entrepreneurship system on the territory of the Volgograd region, provided by the institutional infrastructure, by the regional funds of the business support, the funds of assistance to crediting agencies for enterprise development 
and public associations of entrepreneurs. It is necessary to consider the key ones.

The Association (non-profit partnership) "The guarantee fund of the Volgograd region", created in 2007 with the participation of the regional public organization "Volgograd center for protection and development of business "Delo", as well as the Volzhsky and Volgograd city administrations, ensures development of the lending system to small and medium-sized businesses of the Volgograd region, by providing sureties for loans to small and medium-sized businesses.

Since the beginning of the Association "GF VO", the guarantee issue volume to small and medium-sized businesses of the Volgograd region amounted to 2645.25 million rubles, while the volume of loans received by the subjects in the bank partnership amounted to 5 810.44 million rubles. The association provided guarantees to 53 SMEs in the amount of 408.5 million rubles for loans in the amount of 955.7 million rubles in 2018 [11]. It is important to note that this structure provides support to all enterprises, and its activities don't provide for creation of the special preferential conditions for the innovative companies, which leads to the conclusion about the multidirectional guarantees issued by it and loans attracted.

A similar function is provided by the microcredit company "Fund of the entrepreneurship micro-financing in the Volgograd region", the main activity of which is the provision of microloans (maximum loan amount -3 million rubles) to small and medium-sized businesses at interest rates up to $7.25 \%$ per annum.

According to the information, provided on the official website of the institution, over the past year it was provided the microloans, totaling 60.4 million rubles, to 29 small and medium-sized businesses. The subjects profile, listed on the website, which can be provided with the microloans, similarly complicates the assignment of the fund by the number of organizations, directly supporting the companies innovation and technological orientation.

Formation of a comfortable business environment, creation of the conditions for development of small business, which is included in the technological entrepreneurship field, is engaged in the state autonomous institution of the Volgograd region "Volgograd regional business incubator", providing support to the entrepreneurs at an early stage of their activities, by leasing non-residential premises, equipped with the appliances and furniture on the preferential terms, and providing various additional services. More than 1.6 thousand square meters of the business incubator premises were leased in 2018, the support was provided to 32 small and medium-sized businesses [11].

The structural unit of the business incubator is the engineering center of the Volgograd region, which provides support to the entrepreneurs in the field of industrial engineering and agricultural production. The main purpose of the engineering center is to increase the technological readiness of small and medium-sized enterprises of the Volgograd region to develop new products and introduce innovations and improve their competitiveness.

According to the results of 2018 , the center provided consulting and expert support to 234 small and medium-sized businesses in the field of technological and project engineering, provided 172 engineering services (such as marketing services, consulting services to protect the rights of the intellectual activity results, as preparation of the business plans, services for the product certification, special assessment of working conditions at the enterprise, development of the normative documentation in the field of ecology, design, settlement and analytical services), 143 free consultations were provided [12].

The business support center of the Volgograd region also operates as a structural unit of the business incubator. The center provides free consulting and expert support for business activities (budgeting, tax optimization, accounting services, development of marketing strategy and plans, advertising campaign, design, development and promotion of the brand, drafting and examination of contracts, agreements, constituent documents, job descriptions and instructions, etc.). In addition, the business support center organizes the entrepreneur training in order to improve their skills in implementation of the entrepreneurial activities. 
The center provided free consulting and expert support for business activities to 2,660 small and medium-sized businesses in the region in 2018. Entrepreneurs were provided with consulting support on budgeting, tax optimization, accounting services, marketing, legal, information support of activities. Seminars, round tables and other events for development of entrepreneurship were organized [7].

Another structural unit of the regional business incubator is the export support center, which provides free consulting and expert support to small and medium-sized businesses for the foreign economic activity.

Last year, the center provided information and analytical, consulting and organizational support for foreign economic activity to 270 SMEs. As a result, 18 SMEs signed 30 export contracts. The overall amount of the foreign trade contracts, concluded with the export support center assistance, consisted more than 76 million rubles. During the year, the information and educational events were held on the issues of foreign economic activity, which were attended by 132 SMEs. The educational project of JSC "Russian export center" has been implemented and 64 SMEs were trained under this program in 2018. The international business missions were organized (France, Belarus, Uzbekistan, Turkey, India, Armenia, China) in order to promote Volgograd products for export in 2018 [7].

However, the export support center has practically no real impact on development of the SME's innovative capabilities in the region.

The center of innovations in the social sphere was established in 2018, which provides consulting, educational, information and analytical support to the social entrepreneurship subjects.

At the end of the year, the subjects of social entrepreneurship were provided with 429 consultations, 8 training events, the acceleration programs, the startup fair "Our business-2018" and with the regional stage of the contest "The best social project of the year". 126 SMEs have used the center social innovation support [12].

The coordinating council under the governor of the Volgograd region for small and mediumsized business development and development of competition coordinates the activities of stakeholders for development of small and medium-sized businesses and development of competition in the Volgograd region. The main purpose of the council is to involve small and medium-sized businesses in development and implementation of the state policy in the field of small and medium-sized businesses in the region. The disadvantages of the coordination council under the governor of the Volgograd region include the extremely frequent removability of its staff and, as a consequence, the lack of continuity in its work. On the agenda of the council, the traditional research of the entrepreneurship development issues in the region, including certain types of innovation and technology.

The public organizations, such as the Volgograd chamber of commerce and industry, the Union of the industrialists and entrepreneurs of the Volgograd region, the board of directors of enterprises and organizations of the Volgograd region, the Support of Russia, etc., are created to consolidate the efforts of the business community of the region to participate in formation of the favorable economic, legal and other conditions for development of business. In addition, they are actively involved in the effective cooperation establishment between the entrepreneurs of the Volgograd region and the state authorities, and defend their interests. Recently, the institute of the commissioner for protection of the entrepreneur operating rights in the region began to play an active role in supporting the small and medium-sized business activities. According to the press service of the regional administration, more than 20 million rubles from the Federal and regional budgets will be allocated to develop small and medium-sized businesses in the singleindustry towns of the region - Frolovo and Mikhailovka [13]. The entrepreneurs of these cities will be able to apply for the preferential loans, and the entrepreneurs, engaged in socially significant activities, - for the state subsidies.

Thus, the institutional infrastructure for supporting small and medium-sized businesses in the Volgograd region provides the following forms and types of support:

- financial and credit assistance;

- material assistance;

- organizational-legal assistance;

- consulting assistance; 
- educational assistance.

Based on the fact that the specialized structures, the activities of which are directly related to the support of the technological entrepreneurship, are only two in the considered series - it is the engineering center of the Volgograd region and the center of innovation of the social sphere, it can be concluded that this well-formed support system for classical small and medium-sized enterprises in the region and the state support measures for new innovative types of business activity are extremely insufficient for the further business emergence and development, as a result, also insufficient for raising the region's economy to a new technological level in the future.

\section{Negative trend in development of} small and medium-sized businesses in

\section{the region}

At the same time, despite the relatively wide range of elements of the entrepreneurship support infrastructure in the traditional sense on the territory of the Volgograd region, the statistical indicators of small and medium-sized enterprises in the region indicate the presence of a negative trend in their development (table 1-2).

Table 1. The key executing indicators of the small enterprises (no micro-enterprises)

\begin{tabular}{|c|c|c|c|c|c|}
\hline \multirow[b]{2}{*}{ 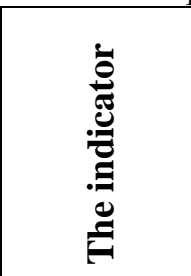 } & \multicolumn{5}{|c|}{ Year } \\
\hline & 2014 & 2015 & 2016 & 2017 & 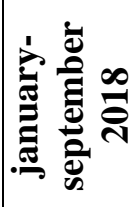 \\
\hline $\begin{array}{l}\text { The number } \\
\text { of } \\
\text { enterprises, } \\
\text { units }\end{array}$ & 3414 & 3081 & 3035 & 2820 & 2526 \\
\hline $\begin{array}{l}\text { The average } \\
\text { number of } \\
\text { the } \\
\text { employees } \\
\text { (including } \\
\text { the external } \\
\text { co-workers } \\
\text { and the } \\
\text { employees } \\
\text { who execute }\end{array}$ & 93519 & 80120 & 73105 & 77254 & 69977 \\
\hline
\end{tabular}

\begin{tabular}{|c|c|c|c|c|c|}
\hline $\begin{array}{l}\text { work under } \\
\text { civil } \\
\text { contracts), } \\
\text { people }\end{array}$ & & & & & \\
\hline $\begin{array}{l}\text { The average } \\
\text { number of } \\
\text { the payroll } \\
\text { employees } \\
\text { (without the } \\
\text { external } \\
\text { part-time } \\
\text { employees), } \\
\text { people }\end{array}$ & - & 73521 & 66799 & 71289 & 64230 \\
\hline $\begin{array}{l}\text { The } \\
\text { turnover of } \\
\text { enterprises } \\
\text { in current } \\
\text { prices; } \\
\text { million } \\
\text { rubles }\end{array}$ & $\begin{array}{l}\hat{\sigma} \\
\hat{\sigma} \\
\tilde{\sigma}\end{array}$ & 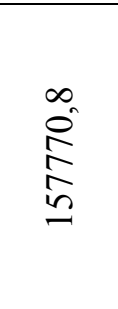 & 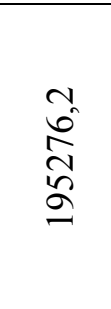 & 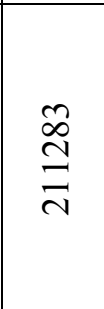 & $\begin{array}{l}0 \\
0 \\
0 \\
\hat{0}\end{array}$ \\
\hline
\end{tabular}

The source: compiled by the author with the materials of the state statistics service of the Volgograd region

Table 2. The key executing indicators of the individual entrepreneurs

\begin{tabular}{|l|c|c|c|}
\hline \multirow{2}{*}{ The indicator } & \multicolumn{3}{|c|}{ Year } \\
\cline { 2 - 4 } & $\mathbf{2 0 1 4}$ & $\mathbf{2 0 1 6}$ & $\mathbf{2 0 1 7}$ \\
\hline $\begin{array}{l}\text { The actual } \\
\text { number of the } \\
\text { active } \\
\text { individual } \\
\text { entrepreneurs, } \\
\text { people }\end{array}$ & & & \\
\hline $\begin{array}{l}\text { The volume of } \\
\text { proceeds } \\
\text { (including the } \\
\text { taxes and } \\
\text { similar } \\
\text { mandatory } \\
\text { payments) from } \\
\text { the sale of } \\
\text { goods, } \\
\text { products, } \\
\text { works, services } \\
\text { for all }\end{array}$ & 139487,5 & 41425 & 41342 \\
$\begin{array}{l}\text { activities, } \\
\text { million rubles }\end{array}$ & & & \\
\hline
\end{tabular}

The source: compiled by the author with the materials of the state statistics service of the Volgograd region

The number of small enterprises and individual entrepreneurs, as well as the average number of employees, steadily reduce every year. 
The data about medium-sized enterprises wasn't provided deliberately, as the state statistics instiltutes in the Volgograd region don't provide data about the number of existing business structures in this segment. The enterprises turnover in current prices cannot be an adequate indicator of business structures development due to the annual growth of prices and stable inflation. Thus, at the end of 2018 in the Volgograd region, food prices increased by $5.2 \%$, which is higher than the inflation rate, which amounted, as the average national rate, $4.3 \%$ [12].

Despite the presence of the export support center of the Volgograd region, the foreign trade indicators of business structures in the region have a negative development trend (figure 1). A significant decline in the foreign trade activity happened in 2015, which was largely due to the deterioration of the geopolitical and macroeconomic situation around Russia, after the events of 2014 in Ukraine. However, it also indicates the absence of a diversified policy of regional enterprises in the markets of the CIS countries, Asia and the Middle East, which should be considered as the most promising in the face of foreign economic uncertainty.

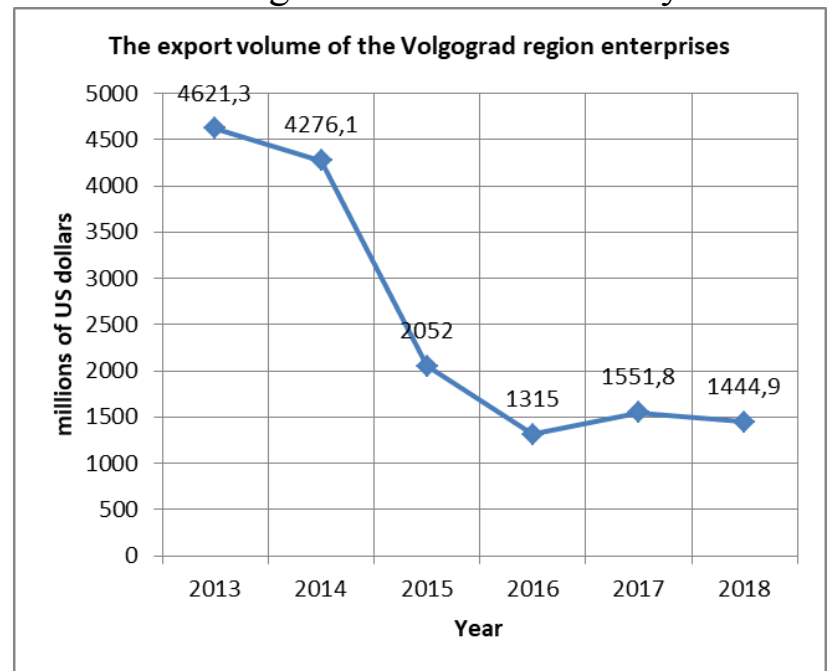

Fig. 1. The export volume of the Volgograd region enterprises

Note from the Publisher: See Fig 1 at the end of the article.

Source: compiled by the author with the materials of the Federal customs service

At the beginning of 2019, the second national report about development of high-tech business in the regions of Russia was published, prepared by specialists of the Russian presidential academy of the national economy and public administration (RANEPA) and the Association of the innovative regions of Russia together with the Interfax Group. According to the methodology of this report, the system of indicators includes two groups of indicators:

- the conditions for development of the hightech business

- the results of its development.

The subsystem of development conditions indicators includes indicators of capital, personnel, scientific potential, quality of institutional environment concentration, such as investment risks and provision of banking services, and infrastructure: innovation, information and communication. The additional block took into account the volume of the state procurement in the high-tech sector of the economy. The subsystem of development results indicators includes an assessment of the contribution of high-tech business to the GRP of the region, exports, creation of new jobs, tax revenues, creation of new business [12].

In the final grouping of the regions by their share in resources and the results of high-tech business development, the Volgograd region is characterized as "medium-sized centers of nonresource growth" with relatively favorable conditions for development. However, for the Volgograd region, the note is made that it is possible to move to a lower group of regions with worse conditions for the development of hightech business [12]. The results of the report show that in the Volgograd region there are no effective institutions to support the system of technological entrepreneurship, contributing to sustainable development of the business and formation of a favorable ecosystem.

\section{Methodology}

The authors propose to improve the efficiency of the infrastructure of state support for technological entrepreneurship by strengthening the targeting of the assistance to small and medium-sized businesses, by narrowing the choice of an alternative support source to solve 
the aforesaid problems. As the public support infrastructure for technological entrepreneurship currently consists of a large number of committees that address a wide range of issues, it is difficult for enterprises to decide which committee they should contact. To solve this problem, first of all, it is necessary to systematize the main problems, arising from the entrepreneurs in the process of their activity development by the power of their influence on business development. Such systematization will make it possible to identify the most important problems and determine which committee is responsible for their solution. For a clearer understanding of the results of the ranking of problems by importance, it is advisable to systematize the problems by constructing a hierarchy, where at its first level will be placed the most significant problems to be solved. At the second level there are the problems that can potentially become the most significant, at the third level - the prospective problems that may receive high importance in the future.

Since the importance and impact of problems that hinder the development of technological entrepreneurship for the purposes of ranking by importance cannot be quantified, for example, as the amount of financial resources or investment, which is estimated in monetary units, so it is necessary to make a qualitative assessment of the importance of problems, the qualitative assessment is understood as assigning verbal assessment to each of the problems identified by entrepreneurs, for example, "very significant", "significant", "weakly significant", through their survey at the first stage of the process of formation where each verbal category will be assigned a quantitative score, for example, "very significant" $=10$ points. Specialists - economists and mathematicians, who are involved in the extraction and processing of knowledge - can develop such a scale of assessment, as well as take into account the impact of environmental factors on the importance of each problem. The expert assessment will allow to build the identified problems by their importance in the form of a hierarchical structure (Figure 2). Thus, it is advisable to use a group of the expert evaluation methods, namely the method of hierarchy analysis (MAI), which allows to present a ranked number of the elements in the form of a hierarchy, to construct a hierarchy of the problems.

The elements are evaluated according to the following algorithm:

As the elements of the matrix are the problems of business development. The comparison of elements is represented as a matrix

$$
\mathrm{C}=(\mathrm{Cij}) \mathrm{i}, \mathrm{j}=1,2, \ldots, \mathrm{n},
$$

$\mathrm{Cij}$ - this is the relation of significance between the $\mathrm{i}$-th and $\mathrm{j}$-th problems. A prerequisite for comparison is: if the elements of the matrix $\mathrm{C}-\mathrm{Cij}=\mathrm{b}$, then $\mathrm{Cji}=1 / \mathrm{b}$, at $\mathrm{b} \neq 0, \mathrm{Cij}=1$.

The matrices of the paired comparisons are square; their filling is carried out according to the following rule. If elements $\mathrm{A} 1$ and $\mathrm{A} 2$, the element A1 dominates A2 element, the cell of the matrix corresponding to the row A1 and column A2 is filled with a natural number $\mathrm{N}$, and the cell of the matrix, corresponding to column A1 and row $A 2$, is filled with the number $1 / \mathrm{N}$. If the elements $\mathrm{A} 1$ and $\mathrm{A} 2$ are equivalent, then the corresponding cells are filled in units.

For matrix matching, as already mentioned in [8], the most accurate way is to find the main eigenvector of the matrix, which becomes the priority vector after normalization. The main eigenvector of the matrix $\{\mathrm{W} 1 ; \mathrm{W} 2 ; \ldots \mathrm{Wn}\}$ is calculated as follows:

$$
W_{1}=\sqrt[n]{c_{1} / c_{1} * c_{1} / c_{2} * \ldots * c_{1} / c_{n}}
$$

where $\mathrm{C} 1$ is an element of the matrix of paired comparisons;

$\mathrm{n}$-dimension of the matrix;

$\mathrm{Wn}-$ an event that is most likely to solve the stated problem.

After determining the main eigenvector, it follows calculation of the priority vector, which will eventually represent the weights of the evaluation criteria. The priority vector is obtained by normalization:

$$
S=W_{1}+W_{2}+\ldots+W_{n}
$$

where $\mathrm{S}$ is the value sum of each element of the main eigenvector of the matrix.

$$
W_{p}=W_{1} / S+W_{2} / S+\ldots+W_{n} / S=1
$$

where $\mathrm{Wp}$ is a vector of priorities;

$\mathrm{W} 1 / \mathrm{S}$ - the elements of the priority vector. 
Another advantage of the method, proposed by the authors, is the ability to determine the efficiency of the developed measures, it requires a matrix $\mathrm{C}$ to be multiplied from the right side on the obtained estimate of the priority vector. For this operation each column of judgments is summed, and then the sum of the first column is multiplied by the value of the first component of the normalized priority vector. The second and next columns are in the same way, a new vector is obtained.

Next, the first element of the new vector is divided by the first element of the vector of priorities, the second element of the new vector by the second element of the vector of priorities and so on, that's another vector. Next move is to divide the sum of the elements of this vector by the number of matrix elements. Then the obtained numbers are summed, and we obtain the value $\lambda \max$ - the approximate value of the maximum eigenvalue of the matrix. The regulatory vector is obtained in the following way; the first move is to calculate the right eigenvector of the matrix calculation which is carried out on the basis of the following equation.

$$
\lambda_{\max }=d_{1} * W_{1}+d_{2} * W_{2}+\ldots+d_{n} * W_{n},
$$

where $\mathrm{d} 1 \ldots \mathrm{dn}$ is the multiplication of each row of the matrix;

$\mathrm{W} 1, \mathrm{~W} 2, \ldots . \mathrm{Wn}-$ the eigenvector of the matrix;

For a positive square matrix $[\mathrm{C}]-$ the right eigenvector $\mathrm{W}$ corresponding to the maximum eigenvalue $\lambda \max$. The closer the maximum eigenvalue estimate of the matrix $\lambda \max$ to the dimension of the matrix $n$, the more consistent the result is.

The most effective method of determining the deviation from the consistency of the matrices is to determine the consistency index, which is obtained by comparing the consistency degree of the matrix, filled by the expert and the degree of the matrix consistency, filled randomly. The numerical evaluation of the consistency degree is based on the fact that for a perfectly matched matrix the maximum eigenvalue is equal to its order, it is determined that the consistency ratio shouldn't exceed the value of 0.1 .

IC - consistency index.

$$
I C=\left(\lambda_{\max }-n\right) /(n-1),
$$

где

$\lambda_{\max }$ - the approximate value of the maximum eigenvalue of the matrix.

$\mathrm{n}$ - the dimensionality of the matrix.

The consistency index, obtained in a random manner, also called random index of consistency. Table 2 shows the dependence of the average value of the consistency index from the number of columns or rows $n$ of the matrix.

The uniformity of judgments is also evaluated by the consistency ratio:

$$
O C=I C / M(I C) \text {, }
$$

where $\mathrm{OC}$ is the consistency ratio;

$\mathrm{M}(\mathrm{IC})$ is the average value (mathematical expectation) of the consistency index, a randomly compiled matrix of paired comparisons [C] [9].

After all the calculations, the elements are arranged in a hierarchy (figure 2).

The Consistency Index (IC) and Consistency Attitudes (OC) are used to determine consensus among experts when assessing the relevance of a problem by experts. The use of IC and OC indicators is due to the fact that they have a high degree of credibility as their values are determined without the involvement of experts. And since the consistency of the experts' assessments affects the reliability of the calculation results, a high degree of reliability was required.

This model presents the structure of problems that hinder the development of technological entrepreneurship in a way that is convenient for entrepreneurs. On the first level, there are problems that have the most negative impact on the development of technological entrepreneurship and create serious barriers for it. It is these problems that need to be addressed first of all. Moreover, a solid line highlights the problems that entrepreneurs know about and identify themselves, and a dotted line highlights the problems that were identified by experts in addition to those already identified, as there are hidden problems that entrepreneurs cannot identify clearly because of the nature of their influence. Identification of the most significant problems makes it possible to solve the problem of selecting a committee that will provide state support for their solution.

At the second level there are less significant problems, but potentially dangerous, as they can 
under certain environmental conditions increase their negative impact on the sphere of technological entrepreneurship, so entrepreneurs must keep these problems under control in order to solve them in time.

At the third level, problems that have a weak impact on technological entrepreneurship are placed, but entrepreneurs should be aware of their existence and monitor them periodically.

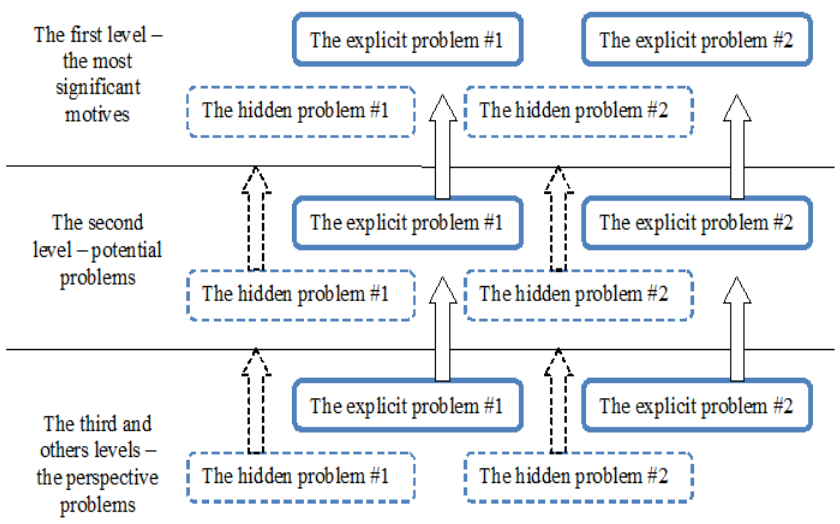

Fig. 2 The hierarchical model of the entrepreneurship development problems

\section{Note from the Publisher: See Fig 2 at the end} of the article.

В целом the hierarchy will allow to present in more detail what problems require the immediate solution, what institutions will help to solve them and moreover, the hierarchy will allow to develop concrete actions for the solution of the development problems of the business sector.

\section{Results}

The low efficiency of the state support measures for small and medium-sized businesses, including its innovative types, provided in the region is a consequence of the current systemic limits of entrepreneurship development. The limits still include insufficient budget financing of the state support measures, which can be used only by a limited number of the business entities, problems with obtaining loans, as well as high interest rates on them, reducing demand for certain categories of goods and services, increasing inflation risks, imperfection of the competitive allocation mechanism of the budgetary funds, as well as the presence of administrative barriers to budgetary stimulation [3].

This is also evidenced by the results of the representative survey of small and medium businesses in Volgograd. The respondent sample was 58 people (28 people - medium business, 30 people - small business). The respondents were chosen from among friends and acquaintances. Communication with the respondents was carried out through the text chat in messengers (Vkontakte, WhatsApp, Viber), as well as personal communication.

The survey results showed that the vast majority of entrepreneurs in the region (88\%) were aware of the existence of Federal and regional business support programs. A little more than half (54\%) have applied for the state support over the past 5 years. However, almost all of the entrepreneurs, who were interviewed, talked about the low efficiency, and often the formality of the proposed forms of support. $36 \%$ of the respondents said that the most effective form of support for entrepreneurship, and primarily technological, was subsidizing part of the costs of small and medium-sized businesses associated with the acquisition of equipment for the creation, development or modernization of production, implemented in accordance with the resolution of the Administration of the Volgograd region in October 21, 2015, N 628-p "About the provision of the subsidies for the state support of small and mediumsized businesses."[11]. This form of support was suspended due to the limited regional budget. Although formally, it continues to be listed as a valid form of support for entrepreneurship.

Among the shortcomings of support for the real sector of the economy in the Volgograd region it should also include the lack of programs to support small and medium-sized businesses, which subsidized with the loan rates for the purchase of the industrial equipment and at least part of the costs of connecting to the networks, the provision of the land to these enterprises without competition, the establishment of preferential rent for them if small and medium-sized businesses are focused on the creation of high-tech jobs.

In addition, the inefficiency of the existing infrastructure to support technological entrepreneurship, caused by the problems that are built in a hierarchical structure in terms of importance (figure 2), may be justified, firstly, by the fact that $38 \%$ of respondents mentioned that it was quite difficult to navigate in a large number of types of support and structures that were responsible for them, namely methods to determine what kind of assistance was necessary for development of the technological entrepreneurship. Secondly, the low level of development of enterprises in the sphere of technological entrepreneurship, which is proved by their small share in the total composition of the enterprise, namely, $4.3 \%$. Third, the narrow sphere of coverage, only 7 industries have technological entrepreneurship and, finally, the low level of funding 
for scientific research, which is only $29 \%$ of the net profit of enterprises.

Thus, it is necessary to develop a methodology to assess the importance of problems that hinder the development of technological entrepreneurship, which is presented by the authors in the section methodology.

Another omission in the system of the regional infrastructure to support small and medium-sized businesses is the neglect of the university role in development of the potential of the technological entrepreneurship. Modern universities, especially engineering and technical profile, are the main source of innovation and advanced scientific and technical developments [14]. The organization of network interaction between educational institutions and business communities of the region by building intensive communication between stakeholders can be a driver of not only technological entrepreneurship, but also the contribution to formation of a favorable ecosystem of business.

The best solution for this situation can be authorization of the regional executive authorities to organize such interaction, in the case of the Volgograd region - the Committee for economic policy and development of the Volgograd region, which has the department of support for innovation in its organizational structure, directly interested in improving the indicators of innovative development of the territory economy and has all the necessary resources to establish appropriate links. The coordination of such engagement element may be accomplished by the council of the Volgograd region on science and innovation, governing the relations of the Volgograd state authorities with the legal entities and individuals engaged in innovation activities on the territory of the Volgograd region, and approved by the decree of the Governor of the Volgograd region from 04.09.2015, No. 804 "About formation of council of the Volgograd region on science and innovation."

\section{Conclusion}

By summarizing the results of the study, key findings can be systematized:

- statistical data indicate negative trends in the development of the sphere of technological entrepreneurship, as the share of enterprises in this sphere is only $4.3 \%$ of the total number of enterprises, technological entrepreneurship has spread only to a few spheres of economic activity in the region, the share of allocations for research and development is small and amounts to $29 \%$ of the free invested funds of enterprises.
- The main constraints in the development of technological entrepreneurship are: lack of financial resources and inefficient infrastructure for state support.

- Inefficiency of the state support infrastructure is connected with redundancy of committees of its components and duplication of the same functions by these committees, as well as with difficulty of choice of the necessary committee by entrepreneurs.

- The difficulty in selecting a committee that is part of the infrastructure of state support for technological entrepreneurship is also related to the difficulties in identifying priority problems that hinder the development of this area. It is difficult for entrepreneurs to determine which of the problems is the most important and which needs to be addressed as soon as possible and which is insignificant.

- To solve the above problems, the authors proposed an algorithm based on the method of analyzing the hierarchies, ranking the problems by their importance and building these as a hierarchical structure. This structure will allow to present in an understandable form what problems need to be solved as soon as possible and what problems do not. Clear definition of significant problems will allow solving the problem with the choice of the necessary committee of state support.

The modern development conditions of the regional territories largely determine the necessity for the process of increasing the share of technological business in the total volume of small and mediumsized businesses.

Traditionally, the catalyst for the growth of such enterprises is the provision of the state support measures, which, as it was found out, is not completely implemented in the Volgograd region.

The solvation of this problem in the region is considered as possible through the establishment of a three-way connection of the cluster type between the business community, research organizations and the government. The implementation of an effective dialogue will ultimately optimize the regional legislation in terms of supporting technological entrepreneurship (eliminate "non-working" measures and increase the number of real ones), reduce administrative barriers to its development and, as a result, reduce the percentage of the legal entity migration to other regions of the country. It will raise the region's economy to a qualitatively new level of development. 


\section{References:}

[1] Fritsch, M., Wyrwich, M. The effect of entrepreneurship on economic development-an empirical analysis using regional entrepreneurship culture, Journal of Economic Geography, No 17(1), 2018, pp. 157-189. Doi: 10.1093/jeg/lbv04

[2] Huggins, R., Waite, D., Munday, M. New directions in regional innovation policy: a network model for generating entrepreneurship and economic development, Regional Studies, No 52(9), 2018, pp. 1294-1304. Doi: 10.1080/00343404.2018.1453131

[3] Dobyndo M. N. The entrepreneurship development as a prerequisite for the sustainable innovation transformation of the regional economy, The regional economy: theory and practice, No. 13, 2007, pp. 55-62.

[4] Barinova V. A., Zemtsov S. P., Tsareva Yu. V. The entrepreneurship and institutions: is there a connection at the regional level in Russia? The economic issue, No. 8, 2018, pp. 92-116.

[5] Khandramay A. A. The technological entrepreneurship of Russia: the economic role, features of development, mechanisms of activation, Economics and entrepreneurship, №8-1(85), 2017, pp. 475-482.

[6] Dolinskaya A. Yu. The technological entrepreneurship is a new opportunity for modern business / Science of Southern Ural State University. The content of the 67th scientific conference, 2015, pp. 1072-1077.

[7] Klechin Yu. I. The innovative approaches in organization of the technological business / The Russian regions at the focus of change. The papers collection of the XI International conference, 2016, pp. 1109-1116.

[8] Khusaenov R. R. The technological entrepreneurship in the conditions of innovative economy: the essence, risks, conclusions / Economic forum "Economy in a changing world". The materials of the Economic forum with the international participation. The collection of scientific articles, 2017, pp. 291292.

[9] Korzuk D. I., Tekucheva S. N. The essence of the technological entrepreneurship, The International Journal of Professional Science, No. 3, 2018, pp. 14-24.

[10] The Global Innovation Index 2018: Energizing the World with Innovation. Ithaca, Fontainebleau, and Geneva. [El. resourses]. URL: https://www.wipo.int/edocs/ pubdocs/en/wipo_pub_gii_2018.pdf (data of the application: 06.03.2019).

[11] About the approval of the state program of the Russian Federation "Economic development and innovative economy" (with the changes for 19 of September, 2018) [Electronic resource]: the order of the Government of the Russian Federation of 15 April, 2014, No. 316 - the access mode: http://docs.cntd.ru/document/499091764

[12] The national report "High-tech business in the regions of Russia". The issue 2 / ed. Zemtsov S. P., M.: RANEPA, AIRR, 2019. 108 p.

[13] Stepanchenko K. V. The institutional problems of entrepreneurship development in Russia, Economics and entrepreneurship, No. 12 (Part 4), 2017, pp. 642-646.

[14] Volkov S. K., Guschina E. G., Vitalieva E.M. The university as a driver of the territory positioning, The modern science-intensive technologies. The regional supplement, No. 3 (51), 2017, pp. 16-23.

[15] Saati T. The decision-making. The method of the hierarchy analysis: [translated from english] / T. Saati., M.: Radio and communication, 1993, $316 \mathrm{p}$.

[16] Nichols S.P., Armstrong N.E. Engineering Entrepreneurship: does entrepreneurship have a role in engineering education? IEEE Antennas and Propagation Magazine, vol. 45, No. 1, 2003, pp. 134-138.

[17] Bailetti T. Technology Entrepreneurship: Overview, Definition, and Distinctive Aspects, Technology Innovation Management Review, vol. 2, no. 2, 2012, pp. 5-12.

[18] Staniec I. Technological Entrepreneurship: How does Environmental Turbulence Impact upon Collaboration Risk? Sustainability, vol. 10, 2018, 2762. DOI 10.3390/su10082762.

[19] Chaston I. Technological Entrepreneurship. Technology-Driven vs Market-Driven Innovation. University of Auckland / New Zealand: Springer International Publishing AG., 2017, 307 p. DOI 10.1007/978-3-319-45850-2.

[20] Jones-Evans D. A typology of technologybased entrepreneurs: A model based on previous occupational background, International Journal of Entrepreneurial Behavior \& Research, vol. 1, no. 1,1995 , pp. 26-47.

[21] Tzu-Hsin Liu, Yee-Yeen Chu, Shih-Chang Hung [et al.] Technology entrepreneurial styles: a comparison of UMC and TSMC, International Journal of Technology Management, vol. 29, no. 1-2, 2005, pp. 92-115. 


\section{APPENDIX}

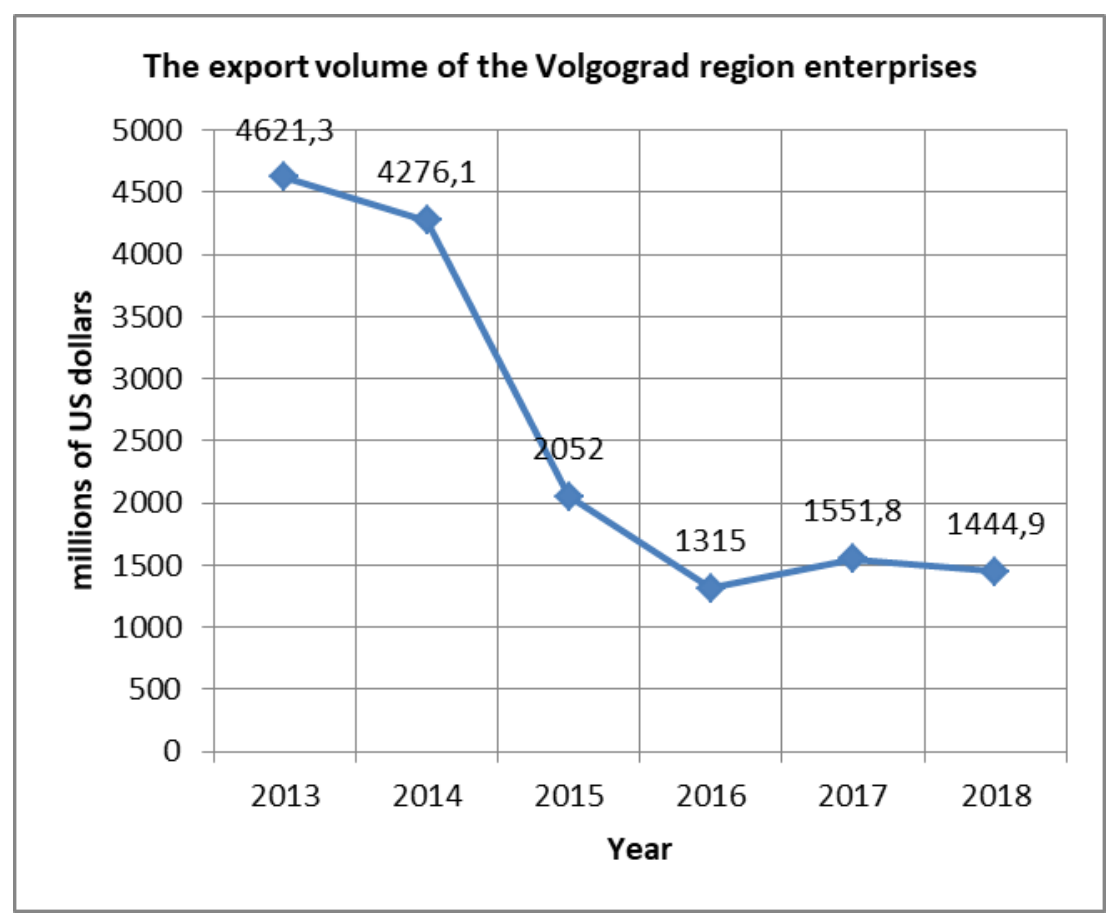

Fig. 1. The export volume of the Volgograd region enterprises

The first level the most The explicit problem \#1

The explicit problem \#2 significant motives

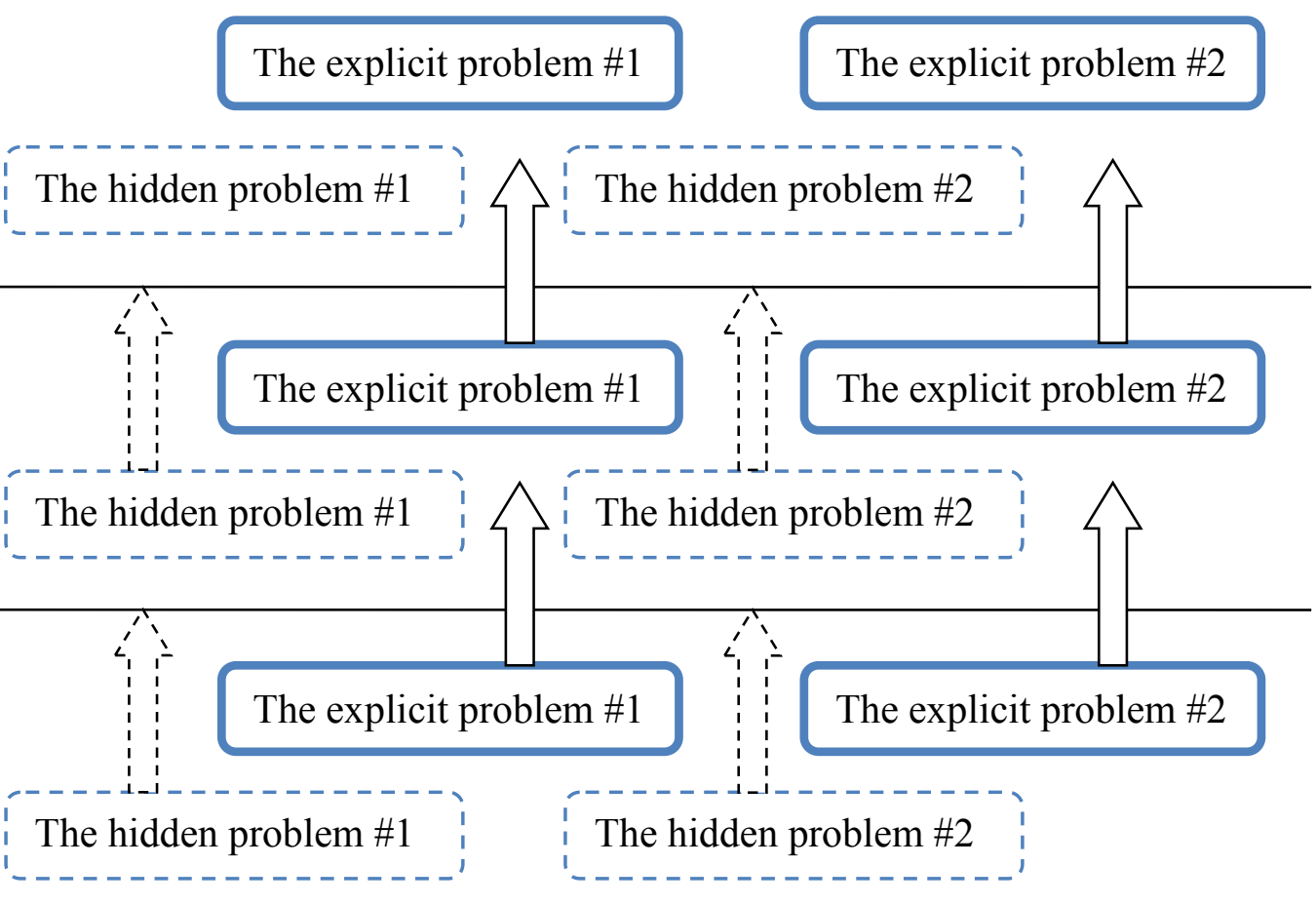
evel - potential problems

The third and others levels the perspective problems

Fig. 2 The hierarchical model of the entrepreneurship development problems 